\title{
A crab swarm at an ecological hotspot: patchiness and population density from AUV observations at a coastal, tropical seamount
}

Jesús Pineda, Walter Cho, Victoria Starczak, Annette F. Govindarajan, Héctor M. Guzman, Yogesh Girdhar, Rusty C Holleman, James Churchill, Hanumant Singh, David K Ralston

A research cruise to Hannibal Bank, a seamount and an ecological hotspot in the coastal eastern tropical Pacific Ocean off Panama, explored the zonation, biodiversity, and the ecological processes that contribute to the seamount's elevated biomass. Here we describe the spatial structure of a benthic anomuran red crab population, using submarine video and autonomous underwater vehicle (AUV) photographs. High density aggregations and a swarm of red crabs were associated with a dense turbid layer 4-10 m above the bottom. The high density aggregations were constrained to 355-385 m water depth over the Northwest flank of the seamount, although the crabs also occurred at lower densities in shallower waters ( $280 \mathrm{~m})$ and in another location of the seamount. The crab aggregations occurred in hypoxic water, with oxygen levels of $0.04 \mathrm{ml} / \mathrm{l}$. Barcoding of Hannibal red crabs, and pelagic red crabs sampled in a mass stranding event in 2015 at a beach in San Diego, California, USA, revealed that the Panamanian and the Californian crabs are likely the same species, Pleuroncodes planipes, and these findings represent an extension of the southern endrange of this species. Measurements along a $1.6 \mathrm{~km}$ transect revealed three high density aggregations, with the highest density up to $78 \mathrm{crabs} / \mathrm{m}^{2}$, and that the crabs were patchily distributed. Crab density peaked in the middle of the patch, $a$ density structure similar to that of swarming insects 


\section{A crab swarm at an ecological hotspot: patchiness and population}

\section{2 density from AUV observations at a coastal, tropical seamount}

4 Jesús Pineda, ${ }^{1, *}$ Walter $\mathrm{Cho}^{2}$, Victoria Starczak, ${ }^{1}$ Annette F. Govindarajan ${ }^{1}$, Héctor M. Guzmán ${ }^{3}$, $5 \quad$ Yogesh Girdhar ${ }^{4}$, Rusty Holleman ${ }^{4,5}$, James Churchill $^{6}$, Hanu Singh ${ }^{4}$, and Dave Ralston ${ }^{4}$

$6{ }^{1}$ Biology Department, Woods Hole Oceanographic Institution, Woods Hole, Massachusetts 7 02543, USA

$8 \quad{ }^{2}$ Department of Biology, Point Loma Nazarene University, San Diego, California 92106, USA

9 3Smithsonian Tropical Research Institute, Balboa, Panama

$10{ }^{4}$ Applied Ocean Physics and Engineering Department, Woods Hole Oceanographic Institution,

11 Woods Hole, Massachusetts 02543, USA

12 5San Francisco Estuary Institute, Richmond, California 94804, USA

13 'Physical Oceanography Department, Woods Hole Oceanographic Institution, Woods Hole,

14 Massachusetts 02543, USA

15 Corresponding author: Jesús Pineda

16266 Woods Hole Rd, Woods Hole, Massachusetts 02543, USA

17 jpineda@,whoi.edu 


\section{Abstract}

A research cruise to Hannibal Bank, a seamount and an ecological hotspot in the coastal

22 eastern tropical Pacific Ocean off Panama, explored the zonation, biodiversity, and the

23 ecological processes that contribute to the seamount's elevated biomass. Here we describe the

24 spatial structure of a benthic anomuran red crab population, using submarine video and

25 autonomous underwater vehicle (AUV) photographs. High density aggregations and a swarm of

26 red crabs were associated with a dense turbid layer 4-10 $\mathrm{m}$ above the bottom. The high density

27 aggregations were constrained to 355-385 m water depth over the Northwest flank of the

28 seamount, although the crabs also occurred at lower densities in shallower waters $(\sim 280 \mathrm{~m})$ and

29 in another location of the seamount. The crab aggregations occurred in hypoxic water, with

30 oxygen levels of $0.04 \mathrm{ml} / \mathrm{l}$. Barcoding of Hannibal red crabs, and pelagic red crabs sampled in a

31 mass stranding event in 2015 at a beach in San Diego, California, USA, revealed that the

32 Panamanian and the Californian crabs are likely the same species, Pleuroncodes planipes, and

33 these findings represent an extension of the southern range end of this species. Measurements

34 along a $1.6 \mathrm{~km}$ transect revealed three high density aggregations, with the highest density up to

$3578 \mathrm{crabs} / \mathrm{m}^{2}$, and that the crabs were patchily distributed. Crab density peaked in the middle of

36 the patch, a density structure similar to that of swarming insects. 


\section{Introduction}

Seamounts are distinct oceanic habitats found in all oceans (Wessel, Sandwell \& Kim

2010), yet key first-order ecological processes are not well understood (Clark et al. 2010).

40 Communities of benthic species on seamounts are regionally isolated, with elevated, shallow

41 rocky habitat patches surrounded by deep sedimentary plains. These two environmental axes,

42 type of substrate (hard vs. soft), and depth (gradients in food, light, and oxygen), create

43 horizontal and vertical patterns in faunal zonation (Pitcher et al. 2008; Thresher et al. 2014).

44 These patterns are likely determined regionally by circulation and larval dispersal, and vertically

45 by physical factors and biological interactions. In the pelagic environment, the trapping and

46 concentration of pelagic planktonic biomass around seamounts, due to hydrodynamic and

47 behavioral processes, result in local increase of predators -such as fish and marine mammals

48 (Klimley, Richert \& Jorgensen 2005; Morato et al. 2008; Morato et al. 2010). Thus, seamounts

49 are ecological hotspots in the sense that many biological and physical processes combine to

50 produce high benthic and pelagic biomass, and higher biodiversity. Seamounts are productive -

51 their shallow summits have been fished for centuries and the biomass of zooplankton is

52 unusually high, but debate remains over the mechanism of pelagic biomass enrichment. A

53 commonly cited hypothesis is that zooplankton and fish productivity result from phytoplankton

54 growth due to topographic induced upwelling of nutrients to euphotic waters, but the importance

55 of this mechanism has been recently challenged (Genin \& Dower 2007). Seamounts harbor

56 valuable yet slow-growing resources, such as reef-building corals (e.g., scleractinians), black

57 corals (e.g., antipatharians), soft-corals (e.g., gorgonians), and fish, some of which can live over

58100 years (e.g., orange roughy) (Koslow 1997). These habitats, however, have been under-

59 sampled and understudied, with less than $1 \%$ of all seamounts explored (Clark et al. 2010). The 
60 occurrence of seamounts in open oceans beyond national jurisdiction, and advances in deep-sea

61 fishing practices have resulted in severe anthropogenic pressure on seamount populations, which

62 due to their life history characteristics are among the least resilient populations in the marine

63 environment (Koslow 1997; Schlacher et al. 2010).

64

65

66

67

Pleuroncodes planipes Stimpson, 1860 (superfamily Galatheoidea, family Muninidae, Ahyong et al. 2010) adult crabs, also known as red crabs, tuna crabs, squat lobsters, and "langostilla", occur in pelagic waters and in deep continental shelf and continental slope benthic habitats. Larvae and small individuals $(\sim<2.6 \mathrm{~cm}$ standard carapace length) tend to dominate the pelagic fraction off western Baja California, with larger organisms occurring exclusively in the benthos (Boyd 1967).

Large individuals reproduce, but observations of pelagic ovigerous females and their larvae in waters over bathyal and abyssal depths $(\sim 2000-3500 \mathrm{~m})$ suggests that a fraction of the pelagic population can reproduce as well (Longhurst \& Seibert 1971). P. planipes can be extremely abundant, with accounts of dense pelagic patches up to 7 - $10 \mathrm{~km}$ (Gómez-Gutiérrez et al. 2000). (See also the casual account of a $16 \mathrm{~km}$ patch by B. Shimada, quoted in Boyd 1967.) Off Baja California $P$. planipes is the main prey of large pelagic predators such as yellowfin tuna and skipjack tuna (Alverson 1963). P. planipes is well adapted to its pelagic lifestyle, where it can feed both on phytoplankton, by specialized filtration, and on small zooplankton (Longhurst, Lorenzen \& Thomas 1967). On benthic habitats, galatheoid crabs are deposit feeders and scavangers (Nicol 1932; Lovrich \& Thiel 2011). Benthic P. planipes ingest particulate organic matter (detritus associated with sediments), phytoplankton cells, and small crustaceans, foraminiferans and radiolarians (Aurioles-Gamboa \& Pérez-Flores 1997). When feeding on 
82 bottom sediments containing diatoms, detritus and small organisms, galatheoid crabs' "third

83 maxillipeds... act as brooms" (Nicol 1932), which would disturb and resuspend fine sediment.

84 Most studies on Pleuroncodes planipes have been done in pelagic waters, and have

85 provided little information on the benthic habitat. Boyd (1967) found that benthic P. planipes

86 ranged from $\sim 100$ to $300 \mathrm{~m}$ water depth off western Baja California, with smaller individuals

87 found in shallower bottoms, and population densities up to $11 / \mathrm{m}^{2}$. These distributions correlated

88 with oxygen minima waters, with oxygen levels below $0.5 \mathrm{ml} / 1$. Boyd (1967) and Robinson and

89 Gómez-Gutiérrez (1998) found that some benthic individuals tend to migrate from the bottom to

90 the upper water column. The typical northern geographic range end of $P$. planipes is somewhere

91 in Baja California. Intermittently, particularly during the El Niño phase of the El Niño Southern

92 Oscillation (ENSO), its geographic range expands northward to California (Longhurst 1966;

93 Smith 1985). The southernmost geographic end range of $P$. planipes appears to be somewhere in

94 Costa Rica (Wicksten 2012), where it is thought to overlap with the northern range of

95 Pleuroncodes monodon (Macpherson et al. 2010; Wehrtmann et al. 2010; Wicksten 2012). The

96 center of abundance of pelagic P. planipes is in western Baja California (Longhurst 1968;

97 Brinton 1979; Gómez-Gutiérrez et al. 2000). The distribution and abundance of benthic $P$.

98 planipes is not well documented, particularly south of Baja California.

99 We present findings from a research cruise to Hannibal Bank, a coastal seamount in the

100 Gulf of Chiriquí, Eastern Tropical Pacific coastal ocean off Panama (Fig. 1). This cruise

101 explored the mechanisms that contribute to high densities of benthic and pelagic organisms in an

102 ecological hotspot and examined the seamount biodiversity and the benthic community zonation

103 along the depth gradient. Work included (a) submarine dives to collect, film and observe

104 firsthand the benthic habitats, and onboard DNA extractions of collected benthic invertebrates, 
105 (b) autonomous underwater vehicle (AUV) transects to map population densities of abundant

106 benthic fauna, and (c) hydrographic and velocity measurements over the seamount using a

107 conductivity, temperature, depth (CTD) and oxygen profiler and a hull-mounted acoustic

108 Doppler current profiler. Hannibal seamount and its shallow top, Hannibal Bank, are within the

109 recently created Coiba National Park, a UNESCO World Heritage site, off the Pacific coast of

110 Panama. Hannibal Bank harbors abundant large fish sustaining artisanal fisheries, and is a

111 destination for international sport fishermen. The flat-topped triangular-shaped seamount rises

112 from $450 \mathrm{~m}$ to $\sim 40 \mathrm{~m}$, occupying an area of $83 \mathrm{~km}^{2}$ (Fig. 2). Proximate to the continental shelf

113 edge, it is $\sim 20 \mathrm{~km}$ west of Coiba Island, $60 \mathrm{~km}$ from the main coast, and centered at about $07^{\circ}$

114 24' N - 82 3' W (Cunningham, Guzman \& Bates 2013). Hannibal seamount communities are

115 likely influenced by several physical processes, including synoptic upwelling from December to

116 late April (D'Croz \& O'Dea 2007), low aragonite saturation state (Manzello et al. 2008), low

117 oxygen sub-thermocline waters, low salinity from runoff and precipitation $(\sim 3 \mathrm{~m}$ yearly

118 precipitation), sharp thermal stratification, large internal tides, and a 4 m tidal range (Dana 1975;

119 Pineda, Reyns \& Starczak 2009; Starczak et al. 2011).

120 On the last dive of the research cruise, we observed extraordinarily high densities of

121 anomuran galatheoid crabs near the bottom of the seamount, and an associated turbid layer over

122 the bottom. The encounter was unexpected and mesmerizing, and we documented these

123 observations with high definition video, a photo-transect, environmental water column

124 measurements and genetic analysis of crab samples. Here we report on these observations, and

125 address the following questions: What is the distribution of the crabs along a transect? What are

126 the patterns of variability in abundance within a patch? Is there a relationship between the turbid 
127 layer and the crab aggregations? Are the crabs observed over the Hannibal Seamount the same

128 species as Pleuroncodes planipes found off of California?

\section{Methods}

The cruise onboard the M/V Alucia from 31 March to 20 April 2015 focused on Hannibal

131 Seamount. The "Ministerio del Ambiente de Panama" provided research and export permits, and

132 the US State Department assisted in obtaining cruise permits. Work included ecological surveys

133 over all flanks of the seamount (Fig. 2), and fifteen submarine dives conducted with Nadir, a 3-

134 person submarine, and 11 dives with RV2, a 2-person submarine with more robust sampling

135 capabilities than Nadir. On most missions, the submarines surveyed starting from the bottom of

136 the seamount and continued to the top, working in tandem, within $\sim 150 \mathrm{~m}$ of each other. Twelve

137 transects with the Seabed autonomous underwater vehicle (AUV) complemented the diving

138 missions and surveyed similar areas, collecting benthic imagery. On a typical cruise day,

139 submarines were deployed during the morning and the Seabed AUV in the evening. Here we

140 focus on observations completed on 18 and 19 April 2015, when crab aggregations were detected

141 and studied. Further submarine and AUV observations on crabs were not possible due to

142 technical issues and cruise schedule. A conductivity, temperature, oxygen and depth profile was

143 taken from the M/V Alucia using a Seabird SBE19 plus CTD in the vicinity of the submarine

144 dive and Seabed AUV transect on 18 April 2015 (Fig. 2, blue cross in inset).

\section{AUV observations and density estimation}

146 Seabed AUV conducted transects on the seamount, and obtained images to estimate

147 densities of bottom organisms. Designed specifically for optical imaging of the seafloor (Singh

148 et al. 2004b), the Seabed AUV has been used extensively for coral reef ecology, and other high 
149 resolution imaging applications (Singh et al. 2004a; Williams et al. 2014). It is equipped with

150 high-dynamic range cameras (Singh et al. 2007) to provide species documentation via imagery

151 that can be corrected for the nonlinear attenuation of light in the water. Seabed AUV navigated at

152 a speed of $\sim 20-25 \mathrm{~cm} / \mathrm{s}$ and mean altitude of $3.5-4.5 \mathrm{~m}$ above the bottom along a predefined

153 track, adjusting its altitude using a high frequency acoustic Doppler profiler. Seabed took 1024

154 by 1380 pixel images of the seafloor that was illuminated with a strobe, and recorded

155 temperature, conductivity, depth, and altitude. The camera pixels are square and the field of view

156 is $45^{\circ}$ in the horizontal and $33^{\circ}$ in the vertical. Image width, $x$, is determined from altitude

157 (height above bottom), $z$, by noting that $0.5(x / z)=\operatorname{Tan}(45 / 2)$, which gives $x=0.828 z$. Because

158 the pixels are square, the image height, $y$, is proportional to the number of pixels; i.e.,

$159 y=x(1024 / 1380)$. AUV specific altitude is used for every image, and image area is calculated

160 as $x \cdot y$.

161 The Seabed AUV was programmed to take photographs every $\sim 4$ seconds, with image

162 overlap. We examined every third image (12 s interval), which gave a sequence with no image

163 overlap. The non-analyzed images were used to resolve ambiguities in identification. Images

164 were inspected for crabs and other organisms by eye, and all organisms were counted in each

165 image.

166 Species identification of the crabs was confirmed by DNA barcoding of individuals in

167 our samples (described below). Images from the Seabed AUV were light-corrected and inspected

168 for organisms and type of substrate. A catalog of organisms was created from the photographs,

169 and each morphospecies received a code. Pleuroncodes planipes were easily distinguished in the

170 video recording taken from the submarine dives, and in the Seabed AUV images. To estimate 
171 crab density $\left(\# / \mathrm{m}^{2}\right)$, the number of crabs was divided by estimated image area in each

172 photograph.

173

174

175

176

177

178

179

180

181

\section{Patchiness estimate}

Patchiness of $P$. planipes was estimated with $\mathrm{I}_{\bmod }$ using the formula of Bez (2000) modified by Décima, Ohman \& De Robertis (2010). This index, based on Lloyd's index, considers a transect that does not sample the entire range of the species:

$$
\mathrm{I}_{\text {mod }}=\left[\frac{\sum_{i} z_{i}^{2}}{s\left(\sum_{i} z_{i}\right)^{2}}\right] N
$$

where $z_{i}$ is the density of the crabs in a given image, $s$ is the size of the sampling unit used in the survey (mean quadrat size, $8.93 \mathrm{~m}^{2}$ ), and $N$ is the number of images analyzed. For comparison, we also report the patchiness index of an unidentified stomatopod that was easily detected in the photographs.

\section{Seamount sample collection and genetic barcoding}

The submarines collected benthic organisms opportunistically, using a robotic manipulator arm, a net and a sediment scoop. (Ministerio del Ambiente de Panama permit \# SE/A-18-15.) Collected specimens were stored in a compartmentalized honeycomb quiver or in a larger "biobox". After the submarine dives, the sampled organisms were held in chilled seawater until they were photographed and labelled (e.g., Fig. 3b), preliminary taxonomic identification based on morphology was made, tissue was collected, and DNA extractions were performed onboard. Here, we focus on Pleuroncodes crabs. DNA was extracted using the DNEasy 
190 extraction kits (Qiagen) following the manufacturer's protocol. Upon return to the laboratory at

191 Woods Hole, we conducted a genetic barcoding analysis on the crabs. A portion of the

192 mitochondrial cytochrome c oxidase subunit I (COI) gene was amplified by PCR using the

193 universal HCO-2198 and LCO-1490primers (Folmer et al. 1994). PCR conditions were: $95^{\circ} \mathrm{C}$ for

1943 minutes; 35 cycles of $95^{\circ} \mathrm{C}$ for 30 seconds, $48^{\circ} \mathrm{C}$ for 30 seconds, and $72^{\circ} \mathrm{C}$ for 1 minute; and

$19572^{\circ} \mathrm{C}$ for 5 minutes. PCR products were visualized on agarose gels stained with Sybr Safe (Life

196 Technologies). PCR products were purified using Qiaquick PCR purification kits (Qiagen) and

197 sequenced in both directions (MWG Eurofins Operon). Sequences were analyzed using the

198 Geneious v. 7.1.7 software platform (Biomatters). Because morphological and video examination

199 suggested that the crabs were Pleuroncodes planipes, we also sequenced COI from crabs

200 identified as $P$. planipes from California for comparison (collection details below). Hannibal and

201 California crab sequences were aligned with ClustalW (Larkin et al. 2007) using default

202 parameters. The ends of the alignment were trimmed so that the dataset was complete for all

203 taxa. Uncorrected $\mathrm{p}$ and Kimura 2-parameter distances were calculated and a neighbor-joining

204 tree was constructed in PAUP* (Swofford 2003).

\section{Sample collection in a mass stranding event}

From January to August 2015 there were several mass stranding events of Pleuroncodes planipes crabs on Southern California beaches, documented from news reports, the Lexis-Nexis database, and informal surveys (J. Pineda, pers. obs., Table 1, Supplemental Materials). In June 2015, crabs were observed in a San Diego beach (S. Searcy, Univ. San Diego, pers. com., and J.

210 Pineda, pers. obs.), and most of the crabs on the beach were still alive. At False Point, La Jolla

$211\left(32^{\circ} 48^{\prime} 28.51^{\prime \prime} \mathrm{N}, 117^{\circ} 15^{\prime} 54.96^{\prime \prime}\right)$, we collected galatheoid crabs on 2-5 June 2015, and

212 preserved them in ethanol to provide reference specimens for DNA barcoding of seamount crabs. 


\section{Results}

\section{Submarine observations and AUV mission}

215 On the last diving mission of the cruise, 18 April 2015, the two submarines dived to the

216 bottom by the westward flank of the seamount (Fig. 2). Upon approaching the bottom, a very

217 dense cloud of sediment was encountered; on no other submarine or AUV dive had such a dense

218 cloud been observed (Fig. 3a). Altitude soundings from the submarine indicated that the turbid

219 cloud extended 4 to $10 \mathrm{~m}$ over the ocean floor. As the submarine approached the bottom, a large

220 number of galatheoid crabs were encountered. RV2 took $13 \mathrm{~min}$ and $40 \mathrm{sec}$ high-definition video

221 of the crabs. A few still photographs and other video were taken from within the Nadir.

222

The video clips and photographs show that crabs were sometimes interacting among

themselves (e.g., facing each other pulling out a dead crab) and with other organisms, including a

224

sand eel. In some footage, crabs were sparsely distributed, and appeared to be sedentary. In other 225

footage, benthic crabs were very dense, touching adjacent crabs, with most crabs moving broadly

226

in the same direction (Fig. 3c and d) as a swarm (Video S1, Supplemental Materials). In this

227

footage, some crabs jumped and swam a few 10's of $\mathrm{cm}$ and landed in another spot. A crab

228

outside of the patch moved towards, and merged with the main patch (Fig. 3d). Sand eel, small

229

pelagic fish, shrimp, and a few stomatopods were in close proximity to the crab aggregation.

230

The population observed in the footage was composed of relatively large crabs, with no

231 visible smaller individuals, i.e., $\sim 2.3 \mathrm{~cm}$ carapace length. (See Fig. $3 \mathrm{~b}$ for typical crabs, with

$2322.7 \mathrm{~cm}$ carapace length; carapace length as measured by Gómez-Gutiérrez et al 2000). For most

233 of the footage, the submarine hovered 2-3 $\mathrm{m}$ above the bottom, and the submarine and its lights

234 did not appear to affect the behavior of the crabs. The high turbidity immediately above the 
235 bottom extended horizontally for at least 10's of m, and the turbid cloud appeared to be

236 associated with the crab patch. As the two submarines moved up the seamount slope and

237 abandoned the patch, the density of crabs decreased abruptly, and the turbid cloud disappeared

238 (Fig. 3d).

On 19 April 2015, the Seabed AUV was programmed to complete a photo-transect in the same region as the crabs seen on 18 April. The AUV dived to about $325 \mathrm{~m}$, and then completed a $1,610 \mathrm{~m}$ transect which included a set of turns to avoid potential high risk areas (e.g., rocky

242 pinnacles) (Fig. 2., inset) Mean image width and length for this transect were 3.46 and 2.57, m,

243 yielding a mean area per image of $8.93 \mathrm{~m}^{2}(\mathrm{n}=580)$. Mean AUV altitude and speed was $4.18 \mathrm{~m}$,

244 and $0.23 \mathrm{~m} / \mathrm{s}$. The 580 analyzed photos were taken at $12 \mathrm{~s}$ intervals, and consecutive images had

245 a gap of $2.78-2.57=0.21 \mathrm{~m}$. (See Fig. 4 for an image from the AUV, with the highest density 246 of crabs detected in the transect, 77.2 individuals $/ \mathrm{m}^{2}$ ).

247 At depths in the region were crab swarms were observed ( $\sim 355-385 \mathrm{~m}$, Northwest

248 flank) and collected (see below), including areas with crabs and with no crabs, substrate type was

249 sedimentary, and sediments appeared to be fine sand and silt, with no rocky substrate.

\section{Pleuroncodes planipes abundance}

$251 \quad$ Pleuroncodes planipes were detected in $12.2 \%$ of the Seabed AUV photographs. Images

252 with counts of $P$. planipes tended to center around 365-m water depth (Fig. 5). Crabs were rare

253 in the shallowest and deepest images, with bins centered at 305 and $405 \mathrm{~m}$, although the number

254 of images from these depths was low. Peak densities, with up to $72.2 \mathrm{crabs} / \mathrm{m}^{2}$, occurred at 360

$255-380$ depths (Fig. 7). Three high-density patches were constrained to depths between 362 and

$256381 \mathrm{~m}$ (Fig. 8, top panel), and were separated from each other by over 100's of meters along the 
257 northing (latitudinal) axis (Fig. 8, lower panel). The distribution of abundance in these peaks

258 indicates that densities were low at the periphery, and that the maxima densities occur near the

259 middle of the patch (Fig. 9). The distribution of crabs along the transect was very patchy, with

$260 \mathrm{I}_{\mathrm{mod}}=5.34$. Unidentified stomatopods that always occurred as singletons in the images had $\mathrm{I}_{\mathrm{mod}}=$

261 3.54. The turbid layer was not apparent in the Seabed AUV images.

262 Galatheoid crabs DNA barcode ID

263 We obtained COI sequences for 6 specimens from Hannibal seamount and 4 specimens

264 from the Pleuroncodes planipes stranding in California. Sequences were deposited in GenBank

265 (Hannibal, KU179422-26, KU179431; La Jolla, KU179427-30). Five out of the 6 Hannibal

266 specimens were obtained from the main crab swarm on 18 April 2015. The $6^{\text {th }}$ specimen was

267 obtained on 3 April 2015, at a depth of $278 \mathrm{~m}$, when crabs were observed on the bottom at the

268 Northwest flank of the seamount (near $7^{\circ} 21.21^{\prime} \mathrm{N}, 82^{\circ} 1.37^{\prime} \mathrm{W}$ ) at low densities. The final

269 alignment for the combined seamount and California dataset was 595 base pairs. Inspection of

270 the amino acid translation indicated that the sequences did not represent pseudogenes. Sequences

271 differed from each other by between 1 to 8 base pairs. Uncorrected $\mathrm{p}$ and Kimura 2-parameter

272 distances were similar to each other and ranged from $0.00168-0.01363$. There were no shared

273 haplotypes and the mean pairwise distance (for both metrics) between Hannibal specimens was

274 greater than the mean distance between Hannibal and California specimens (Table 1, Fig. 6).

\section{Water properties}

276 The CTD cast revealed strong temperature, salinity, and oxygen stratification (Fig. 10).

277 The temperature profile showed a sharp thermocline in the upper $40 \mathrm{~m}$, with a temperature drop

278 from $28.5^{\circ} \mathrm{C}$ at the surface to $17.4^{\circ} \mathrm{C}$ at $40 \mathrm{~m}$, and a near-bottom temperature of $11.1^{\circ} \mathrm{C}$ at $\sim 365$

$279 \mathrm{~m}$. A halocline was also observed, with a salinity drop from $33.4 \mathrm{psu}$ at the surface to $34.8 \mathrm{psu}$ at 
$28040 \mathrm{~m}$. Maximum salinity occurred at mid depths (34.9 psu at $180 \mathrm{~m}$ ), with a slight freshening 281 with increasing depth (to 34.8 psu at $365 \mathrm{~m}$ ).

282 Oxygen concentration decreased rapidly with depth, from over $4.8 \mathrm{ml} / 1$ at the surface to $2831.1 \mathrm{ml} / \mathrm{l}$ at $50 \mathrm{~m}$, and was less than $1.0 \mathrm{ml} / \mathrm{l}$ deeper than $250 \mathrm{~m}$. The lowest oxygen value, 0.04 $284 \mathrm{ml} / 1$, was obtained from the deepest measurement, $365 \mathrm{~m}, \sim 15 \mathrm{~m}$ above the bottom. Thus, $P$. 285 planipes maximum densities occurred at depths where waters were oxygen depleted. The vertical 286 gradients of temperature and oxygen concentration changed abruptly at about $238 \mathrm{~m}$, with larger 287 gradients seen below $238 \mathrm{~m}$. The vertical salinity also changed at around $238 \mathrm{~m}$, but more subtly. 288 Beam attenuation data from the SBE CTD revealed a turbid layer around $365 \mathrm{~m}$ depth in which 289 optical attenuation tripled.

\section{Discussion}

Based on DNA barcoding, the Hannibal seamount crabs appear to be the same species as

292 Pleuroncodes planipes from California. COI is the most typically used species barcode gene

293 (Bucklin, Steinke \& Blanco-Bercial 2011), and sequence comparisons are frequently based on

294 Kimura 2-parameter (K2P) distances (da Silva et al. 2011). K2P distances may not necessarily

295 be the best distance metric for a given taxon (Srivathsan \& Meier 2012; Collins \& Cruickshank

296 2013), other metrics may not necessarily perform better and the use of this metric permits

297 straightforward comparisons with K2P distances from studies. Uncorrected p distances were

298 similar to the K2P distances, and in both metrics, the mean distance between individuals at

299 Hannibal Seamount was greater than the mean distance between Hannibal Seamount and

300 California. Pairwise mitochondrial COI distances fell within the range of typical intraspecific

301 distances for galatheoids (da Silva et al. 2011). The southern range limit of $P$. planipes is 
302 considered poorly known (Hendrickx \& Harvey 1999), although researchers have suggested

303 Costa Rica (Wicksten 2012), and our observations here, supported by DNA sequences, may be

304 the southernmost record.

Species have distinct patterns of variation in abundance over space, and understanding

306 the factors that determine these patterns and their diversity is a central goal in ecology. Spatial

307 distribution patterns may reflect individual and population processes, including settlement,

308 dispersal, migration (Roa \& Tapia 2000) and behavior. For example, gregarious behavior and

309 swarming in insects may produce characteristic spatial patterns of abundance (Okubo \& Chiang

310 1974). Whereas practically all organisms have patchy distributions at some spatial scale of

311 observation, the causes and consequences of patchiness can reflect fundamental ecological and

312 life history characteristics (Marquet et al. 1993). For example, patchiness can be species specific

313 and vary ontogenetically (Hewitt 1981; Décima, Ohman \& De Robertis 2010), and species that

314 face different degrees of patchiness may have evolved different life history strategies (e.g. Dagg

315 1977). Patchiness, may be driven by external ("vectorial", environmental), reproductive, social

316 (e.g. behavioral) and competitive ("coactive") processes (Hutchinson 1953). Physical-biological

317 interactions, such as the swimming up response of zooplankton and larvae to downwelling

318 currents (Scotti \& Pineda 2007), might also produce patchiness (e.g., aggregation at fronts), and

319 explain why only certain taxa aggregate in particular hydrodynamic settings.

320 The distribution of Pleuroncodes planipes was highly patchy, similar to other galatheoid

321 populations (Freire, González-Gurriarán \& Olaso 1992; Roa \& Tapia 2000), and $\mathrm{I}_{\text {mod }}$ values were

322 higher than those of a stomatopod that occurred at smaller densities than $P$. planipes. The high $P$.

323 planipes densities were constrained to a narrow subset of regions and depth ranges on Hannibal

324 seamount. From the 26 submarine dives ( 15 missions to distinct sites) and the 12 AUV transects, 
325 we observed dense aggregations of crabs in only one region, the Northwestern flank of the

326 seamount, and these aggregations were constrained to $\sim 355-385 \mathrm{~m}$ water depths. The AUV

327 survey detected three peaks in abundance ( $a-c$, Fig. 9), and in peak b, the observed density was

32877 individuals $/ \mathrm{m}^{2}$, one of the highest that have been measured for galatheoid crabs (Lovrich \&

329 Thiel 2011, Table 6.1). Our sampling protocol cannot resolve whether these density peaks are

330 discrete patches or whether aggregations were connected. It is unlikely, however, that crabs in

331 density peak $c$ were connected to crabs in peak $b$, because crab distributions were observed to be

332 constrained to $355-385 \mathrm{~m}$, and the crabs in $b$ and $c$ were separated by shallower depths (Figs. 2

333 and 8).

334

The density distribution within each of the three abundance peaks detected in the survey

335 is consistent with a pattern where density increases toward the center of distribution (Fig. 9).

336 However, we do not know whether the AUV surveyed the center of the patch. The two high-

337 density peaks at $\sim 480$ and $1440 \mathrm{~m}$ along the transect (Figs. 9a and 9c) each have an adjoining

338 lower-density peak. These lower-density peaks may represent budding, small aggregations that

339 have split from the main aggregation, and might grow into larger patches, or they might merge

340 into the larger, adjacent patch. These density distribution patterns are likely due to aggregation

341 driven by the crab's gregarious behavior, and coordinated movement of the aggregation, a

342 phenomenon that has been called swarming. Okubo et al. (2001) describe swarming as a

343 phenomenon where a group of organisms move together. Swarms are arguably one of the few

344 ecological phenomena that possess emergent properties, where the characteristics of the

345 aggregation cannot be simply explained by adding the individual's behaviors (Parrish \&

346 Edelstein-Keshet 1999). In these complex systems, a focus on individual behavior is unlikely to

347 explain the properties of the swarm. Whether all emergent properties in swarms are functional or 
348 not, is an open question (Parrish \& Edelstein-Keshet 1999). The increase in density towards the

349 center is consistent with other organisms that form swarms and aggregations (e.g., insects, krill

350 and schooling fish, Okubo \& Chiang 1974; Okubo, Grünbaum \& Edelstein-Keshet 2001), and

351 patterns of abundance in other gregarious benthic populations where density increases towards

352 the middle of the distribution might reveal a swarming behavior. Two other galatheoid species

353 have patterns where density increases towards the middle of the patch (Freire, González-

354 Gurriarán \& Olaso 1992) but in these European Munida spp. species, the scale of the patches is

355 a few tens of kilometers, compared to the $\sim 100 \mathrm{~m}$ scale observed in our study. It is unclear

356 whether the abundance structure of these Munida spp. and Pleuroncodes planipes patches are

357 caused by the same processes. Dense benthic aggregations of other species of anomuran and

358 brachyuran crabs (king crabs, spider crabs, tanner crabs, lyre crabs) have been observed, and

359 some were related to reproduction (Powell \& Nickerson 1965; DeGoursey \& Auster 1992;

360 Stevens, Donaldson \& Haaga 1992; Stevens, Haaga \& Donaldson 1994).

361 Crabs densities appeared to be higher and more clumped in the submarine video

362 observations than in the AUV images (compare submarine video still frame Fig. 3 with AUV

363 Fig. 4). The submarine video still frames in Fig. 3 were taken when Pleuroncodes planipes were

364 moving as a group, a swarm, and most organisms appeared to be oriented in the same direction.

365 In the AUV images, a consistent crab orientation and the swarm motion were not obvious.

366 Moreover, the turbid cloud observed from the submarine (Fig. 3) was not seen in any of the

367 AUV images. The turbidity cloud was most likely produced by Pleuroncodes planipes activities,

368 as the turbidity disappeared at the edge of the patch, and was not observed outside of the patch or

369 in any other submarine dive or AUV missions. Diurnal patterns of activity might explain the

370 differences in turbidity. Submarine observations were early in the day, whereas the AUV survey 
371 was done in the evening. However, another possibility is that crabs observed from the submarine

372 were in a location with finer, and hence more easily suspended sediments than those surveyed by

373 the AUV survey. However, the locations not far from each other (Fig. 2).

The resuspension of sediment initiated by crab activity may affect the benthic

375

376

377

378

379

environment over the Northwest seamount flank. Feeding of king crabs in waters $\sim 3 \mathrm{~m}$ deep off Kodiak Island, Alaska, resulted in a dense cloud of turbid water (Bradley \& Stephen 2014), and Yahel et al. (2008) found that bottom fish activity was an important mechanism for sediment resuspension and remineralization of organic matter between water depths of $\sim 60$ and $140 \mathrm{~m}$ in Saanich Inlet (Vancouver Island, BC, Canada).

Pleuroncodes planipes occurred at water depths with very low oxygen $(0.04 \mathrm{ml} / \mathrm{l}$ at $\sim 15$ $\mathrm{m}$ above the bottom where the crabs were observed). The affinity of some galatheoids to low oxygen waters, and P. planipes in particular, is known (Boyd 1967; Lovrich \& Thiel 2011). Depth distribution of $P$. planipes and other galatheoids might be related to these low oxygen levels (discussed by Lovrich \& Thiel 2011), but more study is needed to test this hypothesis.

Pleuroncodes planipes occurs in very high densities in the pelagic environment, and this species mass strands yearly in shallow water and intertidal beaches near the center of its pelagic abundance, Bahía Magdalena, Baja California (Aurioles-Gaamboa, Castro-González \& PérezFlores 1994), and more occasionally on California beaches (Table 1, Longhurst 1966; Smith 1985). While we were on hydrographic stations over Hannibal seamount and surrounding areas, we occasionally observed organisms that appeared to be pelagic red crabs swimming swiftly by the stern of the boat at night, illuminated by the vessel lights. Despite multiple attempts, we were 
392 not able to capture a specimen to assess its identity, so the occurrence of $P$. planipes in the water

393 column above Hannibal seamount is unknown.

394 Our observations in Panama were conducted at roughly the same time when mass

395 stranding events were registered in Southern California (Table 1, Supplemental Material), and

396 the Hannibal and Californian individuals appear to be the same species based on their mtCOI

397 sequences. Mass stranding of Pleuroncodes planipes in Southern California beaches has been

398 linked to El Niño (Smith 1985). A full El Niño had not been declared for January-June 2015,

399 when many stranding events were reported (Table 1, Supplemental Material). On the other hand,

400 an unusually large pool of warm water developed in late 2013 and early 2014 in the coastal

401 temperate eastern Pacific, and persisted through much of 2015 (Bond et al. 2015), apparently

402 unrelated to El Niño. The current forecast (February 2015, by NOAA Climate Prediction

403 Center), indicate that the anomalous warm-water pool condition has been followed by an El

404 Niño, and that a full El Niño is currently in progress The "pool or warm water" conditions in

405 January-June 2015 may be related to anomalously warm waters observed in Southern

406 California's nearshore in fall 2014 (Reyns, Pineda, and Lentz, unpub.). These conditions may

407 help explain the appearance of $P$. planipes in Southern California, as speculated by some news

408 outlets. Whereas it is unlikely that that our observations of benthic aggregations at Hannibal are

409 connected with the California mass stranding events, it is significant that $P$. planipes can be

410 simultaneously abundant at the two distant locations and at two different habitats. The high

411 densities of $P$. planipes likely impacted local pelagic, intertidal, and deep seamount food webs.

412 Allochthonous supply of biomass, where resources from one habitat or ecosystem

413 subsidizes another system, influences local population community and dynamics (Polis,

414 Anderson \& Holt 1997). Moreover, the episodic availability of large quantities of biomass to 
415 benthic and pelagic organisms and marine mammals, including the supply of terrestrial material

416 and whale carcasses to benthic deep sea communities, the mass stranding of pelagic organisms in

417 shallow habitats, and the sudden availability of a new resource, represent an opportunistic yet

418 important source of nutrition to the "receiving" communities (Polis, Anderson \& Holt 1997), and

419 can influence food web structure and demographic rates (Watt, Siniff \& Estes 2000). The

420 massive availability of Pleuroncodes planipes might influence diverse food webs.

421 Because of its pelagic and benthic lifestyle, and its abundance, Pleuroncodes planipes

422 likely plays an important role in some seamount, continental shelf and shallow water food webs

423 in the subtropical and sub temperate eastern Pacific. Several authors have noticed the key role of

424 P. planipes in the pelagic environment, by virtue of its abundance and trophic role (Alverson

425 1963; Longhurst 1966; Longhurst, Lorenzen \& Thomas 1967; Gómez-Gutiérrez et al. 2000;

426 Robinson, Anislado \& Lopez 2004). P. planipes was patchy but very abundant at Hannibal, and

427 it might represent an important resource for pelagic predators at the seamount. More research is

428 needed to assess the distribution and abundance of benthic $P$. planipes, as well as its potentially

429 key role in semitropical and sub-temperate eastern Pacific seamount and continental shelf

430 habitats.

\section{Acknowledgements}

We would like to express gratitude for the help and logistical support of the Captain and the crew of the M/V Alucia, the Alucia's submarine team, Jeff Anderson, for programming and

434 running the AUV operations, and keeping it safe, Alex Bocconcelli and WHOI's Marine

435 Operations office support. Bathymetric data in Figure 1 derived from the GEBCO_2014 Grid, 436 www.gebco.net. 


\section{References}

438 Ahyong ST, Baba K, Macpherson E, and Poore GC. 2010. A new classification of the

439 Galatheoidea (Crustacea: Decapoda: Anomura). Zootaxa 2676:57-68.

440 Alverson F. 1963. The food of yellowfin and skipjack tunas in the eastern tropical Pacific Ocean. 441 Inter-Am Trop Tuna Comm Bull 7:295-367.

442 Aurioles-Gaamboa D, Castro-González MI, and Pérez-Flores R. 1994. Annual mass strandings 443 of pelagic red crabs, Pleuroncodes planipes (Crustacea, Anomura, Galatheidae), in Bahia 444

Aurioles-Gamboa D, and Pérez-Flores R. 1997. Seasonal and bathymetric changes in feeding 446 habits of the benthic red crab Pleuroncodes planipes (Decapoda, Anomura, Galatheidae) off the Pacific coast of Baja California Sur, Mexico. Crustaceana 70:272-287.

448

449

450 451

452

453

454

455

456 Magdalena, Baja California Sur, Mexico. Fishery Bulletin 92:464-470.

Bez N. 2000. On the use of Lloyd's index of patchiness. Fisheries Oceanography 9:372-376. DOI 10.1046/j.1365-2419.2000.00148.x

Bond NA, Cronin MF, Freeland H, and Mantua N. 2015. Causes and impacts of the 2014 warm anomaly in the NE Pacific. Geophysical Research Letters 42:2015GL063306. 10.1002/2015GL063306

Boyd CM. 1967. The benthic and pelagic habitats of red crab Pleuroncodes planipes. Pacific Science 21:394-\&.

Bradley GS, and Stephen CJ. 2014. Growth, molting, and feeding of king crabs. In: Bradley GS, ed. King Crabs of the World Biology and Fisheries Management: CRC Press, 315-362. 
457 Brinton E. 1979. Parameters relating to the distributions of planktonic organisms, especially

458 Euphausiids in the eastern tropical Pacific. Progress in Oceanography 8:125-189.

459 Bucklin A, Steinke D, and Blanco-Bercial L. 2011. DNA barcoding of marine metazoa. Annual

460 Review of Marine Science, Vol 3 3:471-508. DOI 10.1146/annurev-marine-120308-

$461 \quad 080950$

462 Clark MR, Rowden AA, Schlacher T, Williams A, Consalvey M, Stocks KI, Rogers AD, O'Hara

463 TD, White M, Shank TM, and Hall-Spencer JM. 2010. The ecology of seamounts:

464 structure, function, and human impacts. Annual Review of Marine Science 2:253-278.

465 Collins R, and Cruickshank R. 2013. The seven deadly sins of DNA barcoding. Molecular 466 ecology resources 13:969-975.

467 Cunningham SL, Guzman HM, and Bates RC. 2013. The morphology and structure of the 468 Hannibal Bank fisheries management zone, Pacific Panama using acoustic seabed 469 mapping. Rev Biol Trop 61:1967-1979.

D'Croz L, and O'Dea A. 2007. Variability in upwelling along the Pacific shelf of Panama and 471 implications for the distribution of nutrients and chlorophyll. Estuarine, Coastal and Shelf Science 73:325-340.

da Silva JM, Creer S, Dos Santos A, Costa AC, Cunha MR, Costa FO, and Carvalho GR. 2011. Systematic and evolutionary insights derived from mtDNA COI barcode diversity in the Decapoda (Crustacea: Malacostraca). Public Library of Science ONE 6:e19449. 
476 Dagg M. 1977. Some effects of patchy food environments on copepods. Limnology and

477 Oceanography 22:99-107.

478

479

480

481

482

483

484

485

486

487

488

489

490

491

492

493

494

Dana TF. 1975. Development of contemporary Eastern Pacific coral reefs. Marine Biology 33:355-374.

Décima M, Ohman MD, and De Robertis A. 2010. Body size dependence of euphausiid spatial patchiness. Limnology and Oceanography 55:777-788.

DeGoursey RE, and Auster PJ. 1992. A mating aggregation of the spider crab (Libinia emarginata). Journal of Northwest Atlantic Fishery Science 13:77-82.

Folmer O, Black M, Hoeh W, Lutz RA, and Vrijenhoek R. 1994. DNA primers for amplification of mitochondrial cytochrome $c$ oxidase subunit I from diverse metazoan invertebrates. Molecular Marine Biology and Biotechnology 3:294-299.

Freire J, González-Gurriarán E, and Olaso I. 1992. Spatial distribution of Munida intermedia and M. sarsi (Crustacea: Anomura) on the Galician continental shelf (NW Spain): application of geostatistical analysis. Estuarine, Coastal and Shelf Science 35:637-648.

Genin A, and Dower JF. 2007. Seamount plankton dynamics. In: Pitcher T, Morato T, Hart P, Clark M, Haggan N, and Santos R, eds. Seamounts: Ecology, Fisheries, and Conservation. Oxford, UK: Blackwell, 85-100.

Gómez-Gutiérrez J, Domínguez-Hernández E, Robinson CJ, and Arenas V. 2000. Hydroacoustical evidence of autumn inshore residence of the pelagic red crab 
495

496

497

498

499

500

501

502

503

504

505

506

507

508

509

510

511

512

513

Pleuroncodes planipes at Punta Eugenia, Baja California, Mexico. Marine Ecology Progress Series 208:283-291.

Hendrickx ME, and Harvey AW. 1999. Checklist of anomuran crabs (Crustacea: Decapoda) from the eastern tropical Pacific. Belgian Journal of Zoology 129:363-389.

Hewitt R. 1981. The value of pattern in the distribution of young fish. Reun Cons int Explor Mer, 178:229-236.

Hutchinson GE. 1953. The concept of pattern in ecology. Proceedings of the Academy of Natural Sciences of Philadelphia 105:1-12. 10.2307/4064466

Klimley A, Richert JE, and Jorgensen SJ. 2005. The home of blue water fish. American Scientist 93:42-49.

Koslow JA. 1997. Seamounts and the ecology of deep-sea fisheries. American Scientist 85:168176.

Larkin MA, Blackshields G, Brown N, Chenna R, McGettigan PA, McWilliam H, Valentin F, Wallace IM, Wilm A, and Lopez R. 2007. Clustal W and Clustal X version 2.0. Bioinformatics 23:2947-2948.

Longhurst AR. 1966. The pelagic phase of Pleuroncodes planipes Stimpson (Crustacea, Galatheidae) in the California Current. CalCOFI Reports XI:142-154.

Longhurst AR. 1968. The biology of mass occurrences of Galatheid crustaceans and their utilization as a fisheries resource. In: Mistakidis MN, editor. Proceeding of the world 
scientific conference on the biology and culture of shrimps and prawns FAO Fisheries Reports Vol 57. Mexico City. p 95-110.

516

517

518

519

520

521

522

523

524

525

526

527

528

529

530

531

532

533

534

Longhurst AR, Lorenzen CJ, and Thomas WH. 1967. The role of pelagic crabs in the grazing of phytoplankton off Baja California. Ecology 48:190-200. 10.2307/1933100

Longhurst AR, and Seibert DLR. 1971. Breeding in an oceanic population of Pleuroncodes planipes (Crustacea, Galatheidae). Pacific Science 25:426-\&.

Lovrich GA, and Thiel M. 2011. Ecology, physiology, feeding and trophic role of squat lobsters. In: Poore GCB, Ahyong, S.T., Taylor, J., ed. The Biology of Squat Lobsters. Boca Raton: CRC Press, 183-222.

Macpherson E, de Forges BR, Schnabel K, Samadi S, Boisselier MC, and Garcia-Rubies A. 2010. Biogeography of the deep-sea galatheid squat lobsters of the Pacific Ocean. DeepSea Research Part I-Oceanographic Research Papers 57:228-238. 10.1016/j.dsr.2009.11.002

Manzello DP, Kleypas JA, Budd DA, Eakin CM, Glynn PW, and Langdon C. 2008. Poorly cemented coral reefs of the eastern tropical Pacific: Possible insights into reef development in a high-CO2 world. Proceedings of the National Academy of Sciences 105:10450-10455. 10.1073/pnas.0712167105

Marquet P, Fortin MJ, Pineda J, Wallin DO, Clark J, Wu Y, Bollens S, Jacobi C, and Holt RD. 1993. Ecological and evolutionary consequences of patchiness: a marine-terrestrial perspective. In: Levin SA, Powell TM, and Steele JH, eds. Patch Dynamics. Berlin: Springer-Verlag, 277-304. 
535 Morato T, Hoyle SD, Allain V, and Nicol SJ. 2010. Seamounts are hotspots of pelagic

536 biodiversity in the open ocean. Proceedings of the National Academy of Sciences

537 107:9707-9711.

538

539

540

541

542

543

544

545

546

547

548

549

550

551

552

553
Morato T, Varkey DA, Damaso C, Machete M, Santos M, Prieto R, Santos RS, and Pitcher TJ. 2008. Evidence of a seamount effect on aggregating visitors. Marine Ecology Progress Series 357:23.

Nicol EAT. 1932. The feeding habits of the Galatheidae. Journal of the Marine Biological Association of the United Kingdom 18:87-106.

Okubo A, and Chiang HC. 1974. An analysis of the kinematics of swarming of Anarete pritchardi Kim (Diptera: Cecidomyiidae). Researches on Population Ecology 16:1-42. 10.1007/BF02514077

Okubo A, Grünbaum D, and Edelstein-Keshet L. 2001. The dynamics of animal grouping. In: Levin SA, ed. Diffusion and Ecological Problems: Modern Perspectives: Springer New York, 197-237.

Parrish JK, and Edelstein-Keshet L. 1999. Complexity, Pattern, and Evolutionary Trade-Offs in Animal Aggregation. Science 284:99-101. 10.1126/science.284.5411.99

Pineda J, Reyns N, and Starczak VR. 2009. Complexity and simplification in understanding recruitment in benthic populations. Population ecology 51:17-32. 10.1007/s10144-0080118-0 
554 Pitcher TJ, Morato T, Hart PJ, Clark MR, Haggan N, and Santos RS. 2008. Seamounts: ecology, 555 fisheries \& conservation. Oxford, UK: Blackwell Publishing.

556 Polis GA, Anderson WB, and Holt RD. 1997. Toward an integration of landscape and food web

557

558

559

560

561

562

563

564

565

566

567

568

569

570

571

572 ecology: the dynamics of spatially subsidized food webs. Annual Review of Ecology and Systematics:289-316.

Powell GC, and Nickerson RB. 1965. Aggregations among juvenile king crabs (Paralithodes camtschatica, Tilesius) Kodiak, Alaska. Animal behaviour 13:374-IN310.

Roa R, and Tapia F. 2000. Cohorts in space: geostatistical mapping of the age structure of the squat lobster Pleuroncodes monodon population off central Chile. Marine Ecology Progress Series 196:239-251.

Robinson CJ, Anislado V, and Lopez A. 2004. The pelagic red crab (Pleuroncodes planipes) related to active upwelling sites in the California Current off the west coast of Baja California. Deep Sea Research Part II: Topical Studies in Oceanography 51:753-766. http://dx.doi.org/10.1016/j.dsr2.2004.05.018

Robinson CJ, and Goómez-Gutieérrez J. 1998. The red-crab bloom off the west coast of Baja California, Mexico. Journal of Plankton Research 20:2009-2016.

Schlacher TA, Rowden AA, Dower JF, and Consalvey M. 2010. Seamount science scales undersea mountains: new research and outlook. Marine Ecology 31:1-13. 10.1111/j.14390485.2010.00396.x 
573 Scotti A, and Pineda J. 2007. Plankton accumulation and transport in propagating nonlinear internal fronts. Journal of Marine Research 65:117-145. 10.1357/002224007780388702

575

576

577

578

579

580

581

582

583

584

585

Singh H, Armstrong R, Gilbes F, Eustice R, Roman C, Pizarro O, and Torres J. 2004a. Imaging coral I: Imaging coral habitats with the SeaBED AUV. Subsurface Sensing Technologies and Applications 5:25-42.

Singh H, Can A, Eustice R, Lerner S, McPhee N, and Roman C. 2004b. Seabed AUV offers new platform for high-resolution imaging. Eos, Transactions American Geophysical Union 85:289-296.

Singh H, Roman C, Pizarro O, Eustice R, and Can A. 2007. Towards high-resolution imaging from underwater vehicles. The International journal of robotics research 26:55-74.

Smith PE. 1985. A case history of an anti-Niño transition plankton and nekton distribution and abundances. In: Wooster WS, and David LF, eds. El Niño North: Niño effects in the eastern subarctic Pacific Ocean. Seattler: Washingthon Sea Grant, 121-142.

Srivathsan A, and Meier R. 2012. On the inappropriate use of Kimura-2-parameter (K2P) divergences in the DNA-barcoding literature. Cladistics 28:190-194.

Starczak VR, Pérez-Brunius P, Levine HE, Gyory J, and Pineda J. 2011. The role of season and salinity in influencing barnacle distribution in two adjacent coastal mangrove lagoons. Bulletin of Marine Science 87:275-299. doi:10.5343/bms.2010.1022 
591 Stevens BG, Donaldson WE, and Haaga JA. 1992. First observations of podding behavior for the

592 Pacific Lyre crab Hyas lyratus (Decapoda: Majidae). Journal of Crustacean Biology

593 $12: 193-195.10 .2307 / 1549074$

594

595

596 597
Stevens BG, Haaga JA, and Donaldson WE. 1994. Aggregative mating of Tanner crabs, Chionoecetes bairdi. Canadian Journal of Fisheries and Aquatic Sciences 51:1273-1280.

Swofford DL. 2003. PAUP*. Phylogenetic analysis using parsimony (*and other methods). Version 4. Sunderland, MA: Sinauer Associates.

Thresher R, Althaus F, Adkins J, Gowlett-Holmes K, Alderslade P, Dowdney J, Cho W, Gagnon A, Staples D, and McEnnulty F. 2014. Strong depth-related zonation of megabenthos on a rocky continental margin $(\sim 700-4000 \mathrm{~m})$ off southern Tasmania, Australia. PLoS ONE 9:Art. No. e85872.

Watt J, Siniff DB, and Estes JA. 2000. Inter-decadal patterns of population and dietary change in sea otters at Amchitka Island, Alaska. Oecologia (Berl) 124:289-298. 10.2307/4222695

Wehrtmann IS, Herrera-Correal J, Vargas R, and P. H. 2010. Squat lobsters (Decapoda: Anomura: Galatheidae) from deepwater Pacific Costa Rica: species diversity, spatial and bathymetric distribution. Nauplius 18:69-77.

Wessel P, Sandwell DT, and Kim SS. 2010. The global seamount census. Oceanography 23:2433.

Wicksten MK. 2012. Decapod Crustacea of the Californian and Oregonian zoogeographic provinces. Zootaxa 3371:1-307. 
611 Williams G, Maksym T, Wilkinson J, Kunz C, Murphy C, Kimball P, and Singh H. 2014. Thick

612 and deformed Antarctic sea ice mapped with autonomous underwater vehicles. Nature 613 Geoscience.

614 Yahel G, Yahel R, Katz T, Lazar B, Herut B, and Tunnicliffe V. 2008. Fish activity: a major 615 mechanism for sediment resuspension and organic matter remineralization in coastal 616 marine sediments. Marine Ecology Progress Series 372:195-209.

617

618

619 


\section{Tables}

621 Table 1. Pairwise distance comparisons for uncorrected $\mathrm{p}$ and K2P distance metrics. Minimum 622 and maximum pairwise distances (for all comparisons) and the mean distances for pairs within 623 and between sampling localities are shown.

\begin{tabular}{|l|l|l|l|l|l|}
\hline & Minimum & Maximum & Within - & Within - & Hannibal - \\
& & & Hannibal & California & California \\
mean & mean & mean \\
\hline Uncorrected $p$ & 0.00168 & 0.01513 & 0.01042 & 0.00336 & 0.00732 \\
\hline K2P & 0.00168 & 0.01536 & 0.01055 & 0.00337 & 0.00734 \\
\hline
\end{tabular}

624 


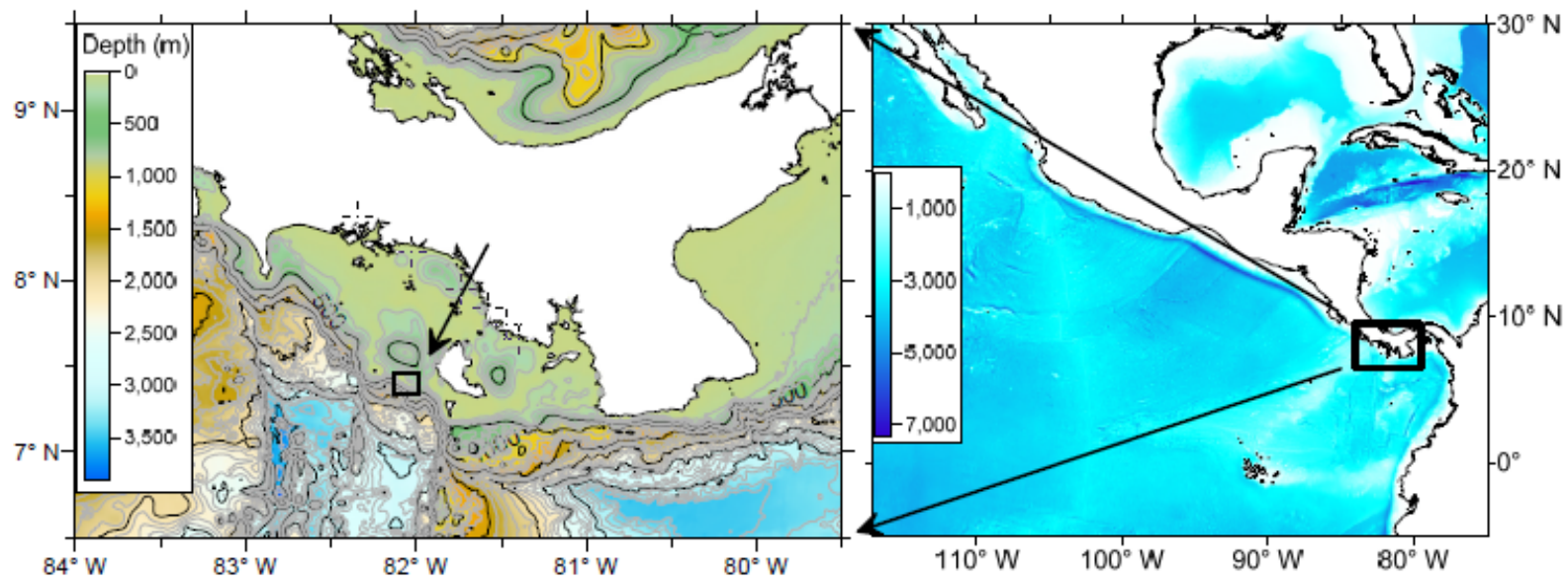

626 Fig 1. Map of the study area. Box in the right panel encloses the left panel, and the small box in

627 the left panel encloses Hannibal Seamount. Bathymetry data from GEBCO. 


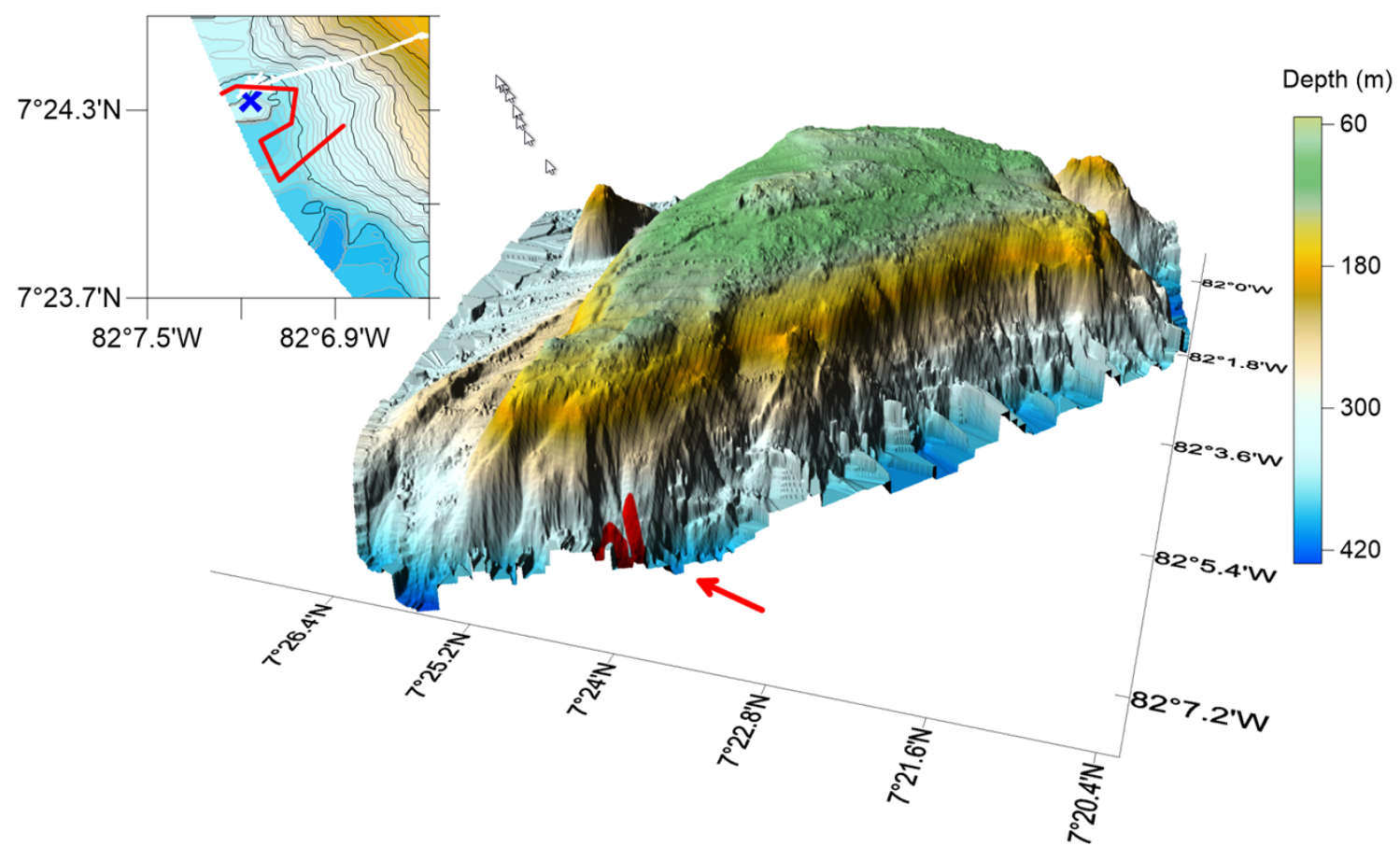

630

631

632 Fig. 2. Hannibal Seamount, with location of the AUV transect indicated with a red line. Insert on

633 the left delineates AUV transect, with end of transect near the blue cross. The blue cross

634 indicates the location of the CTD cast, and the submarine positions are in white. Depth data from 635 Cunningham et al. (2013). 

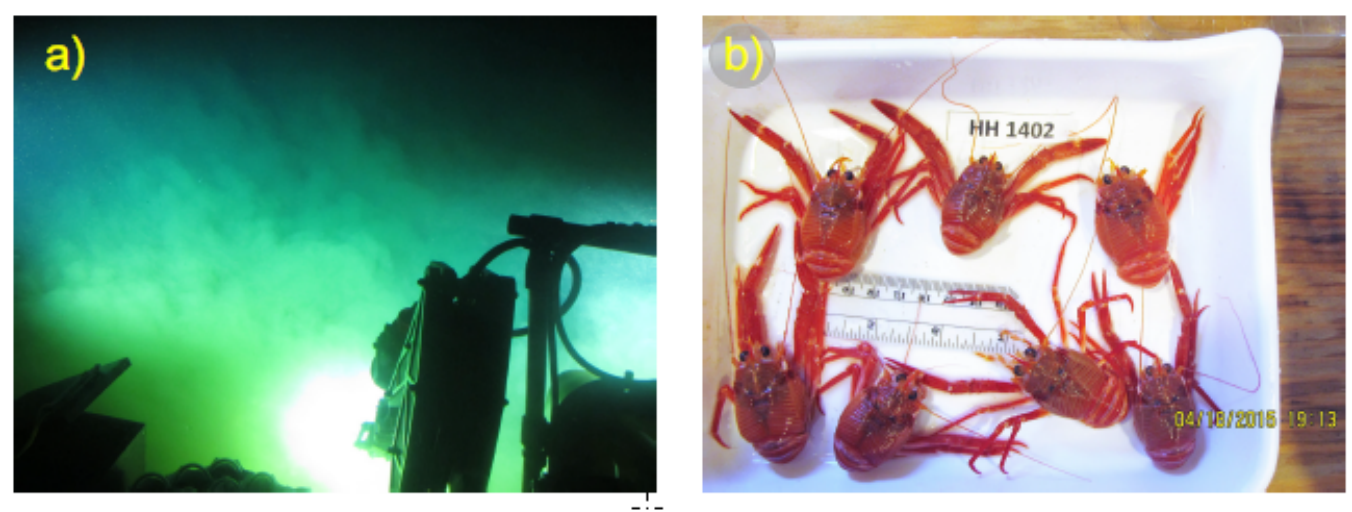

636
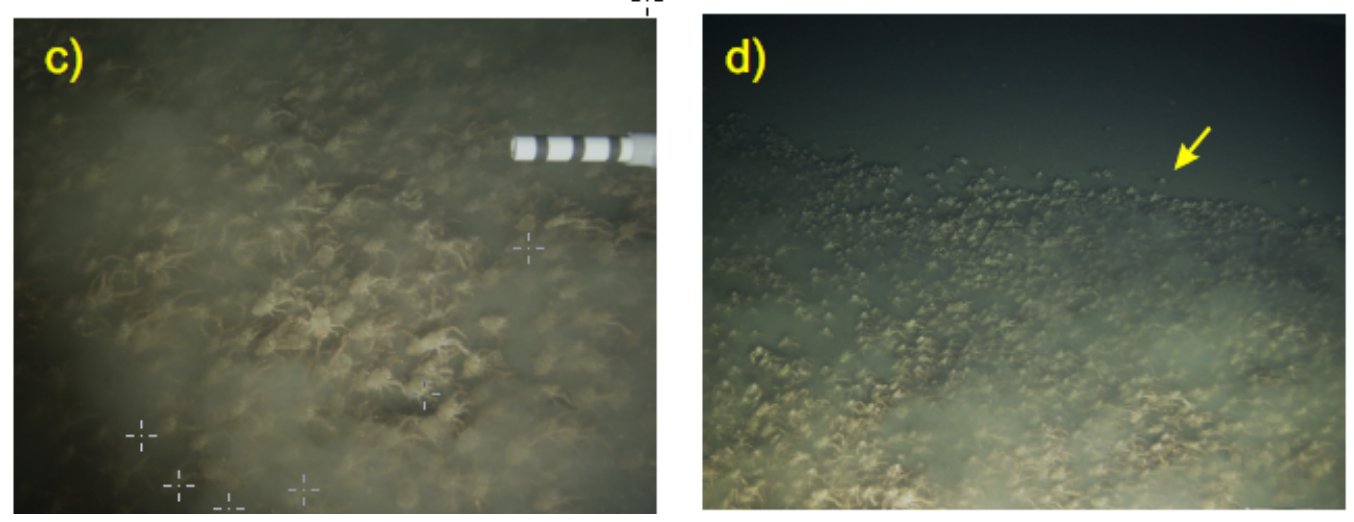

637 Fig. 3. Photographs and video still frames of Pleuroncodes planipes and its environment. a)

638 Image taken within Nadir as it approached the bottom, from about $6 \mathrm{~m}$ above the bottom, where

639 P. planipes aggregations were first found. b) Pleuroncodes planipes collected from the

640 aggregation, with ruler scale in cm and English units. c) Still frame from HD video of a dense

641 patch of $P$. planipes on the bottom. The white PVC segment is about $20.5 \mathrm{~cm}$ long d) Nearbed

642 turbidity dropped at the edges of the Pleuroncodes patch. In the video the crabs were moving on

643 the bottom towards the right, with a few crabs found beyond the boundary of the patch lagging

644 behind the main aggregation. The crab marked with a yellow arrow was separate from the large

645 patch and then merged into the patch by advancing in a direction perpendicular to the direction

646 of patch movement. 


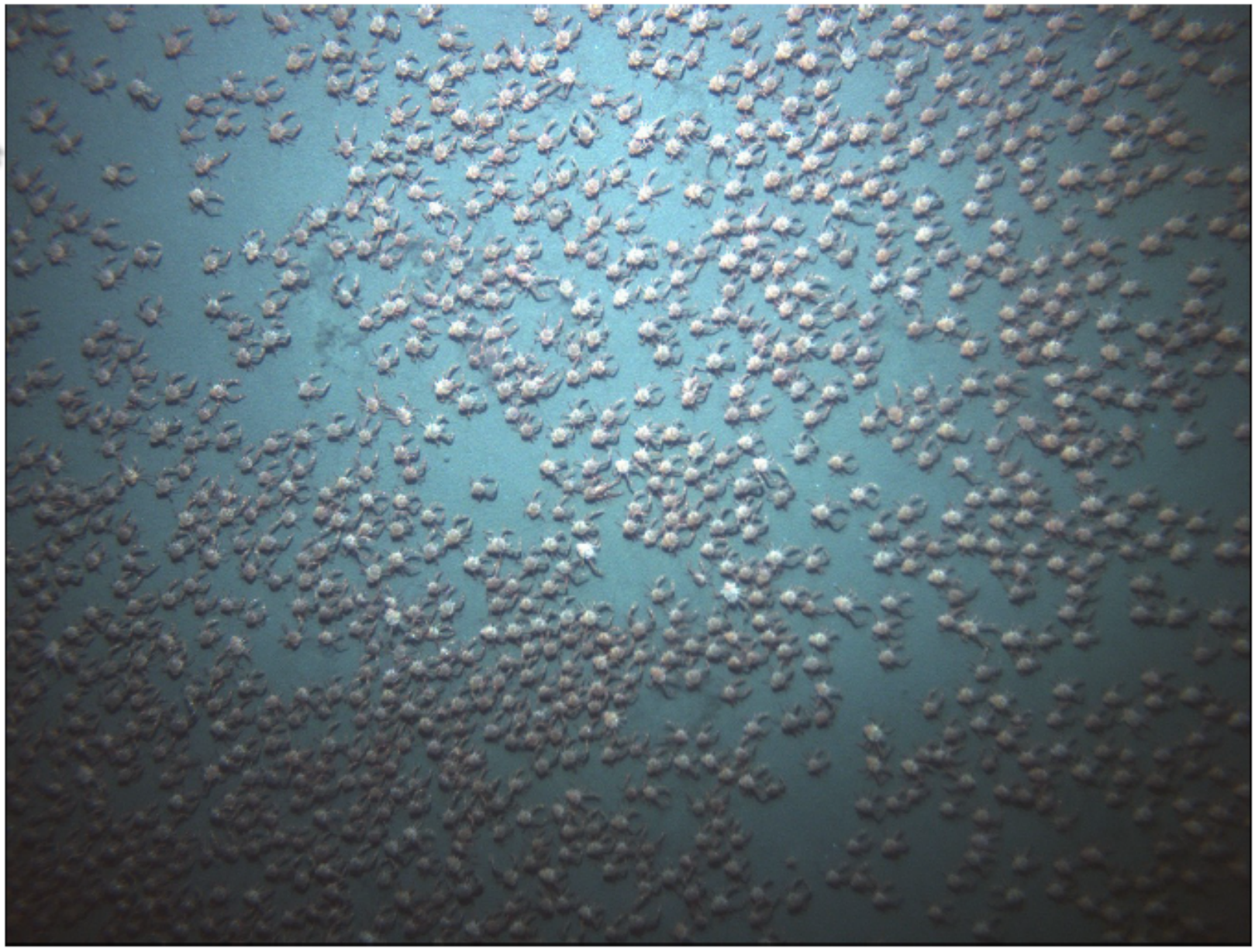

648 Fig. 4. AUV photograph with the highest density of Pleuroncodes planipes.

649

650

651

652

653 


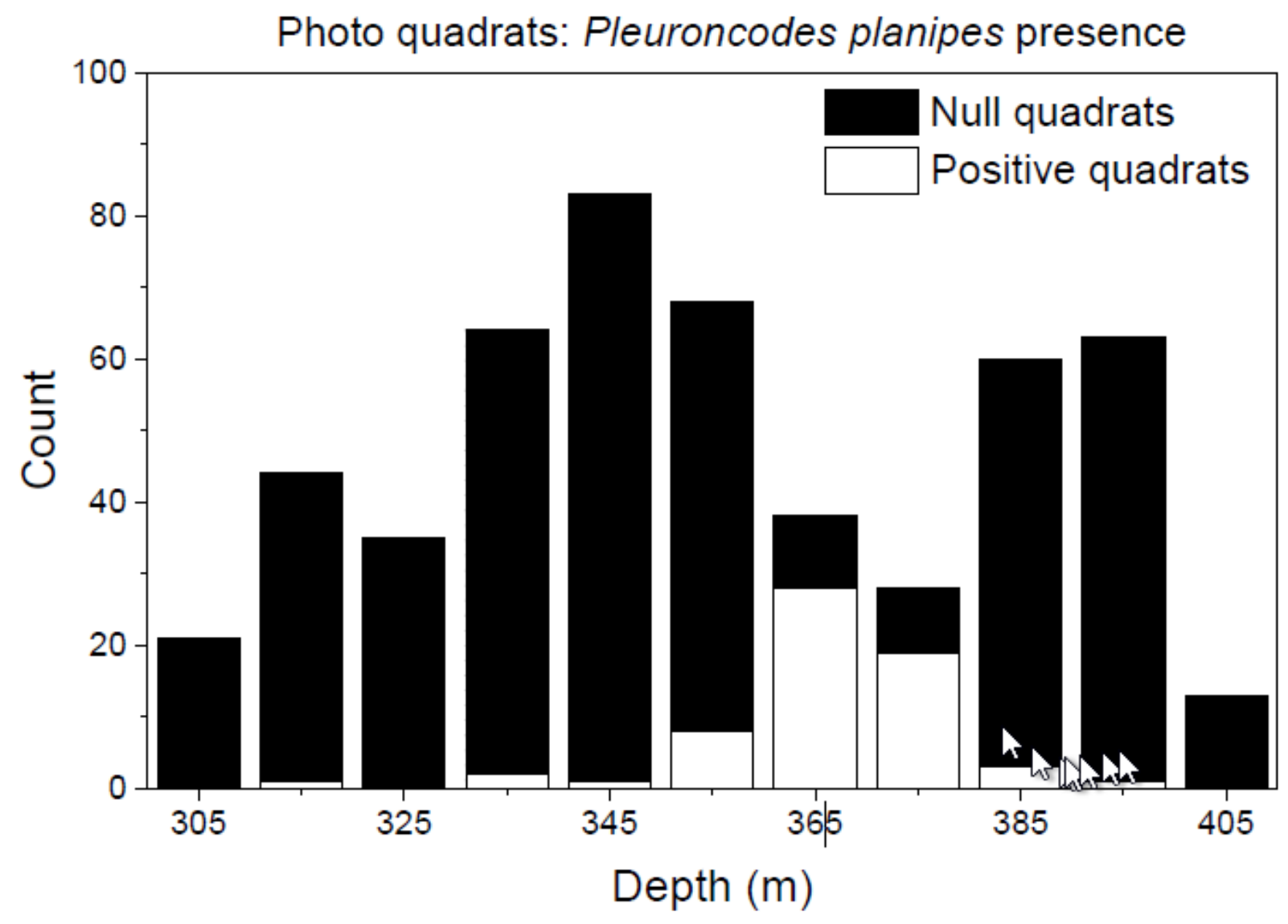

655 Fig. 5 Frequency distribution of quadrats with null and positive Pleuroncodes planipes counts.

656 No $P$. planipes occurred in null quadrats, whereas positive quadrats are those in which at least

657 one $P$. planipes was observed.

658

659

660

661

662 


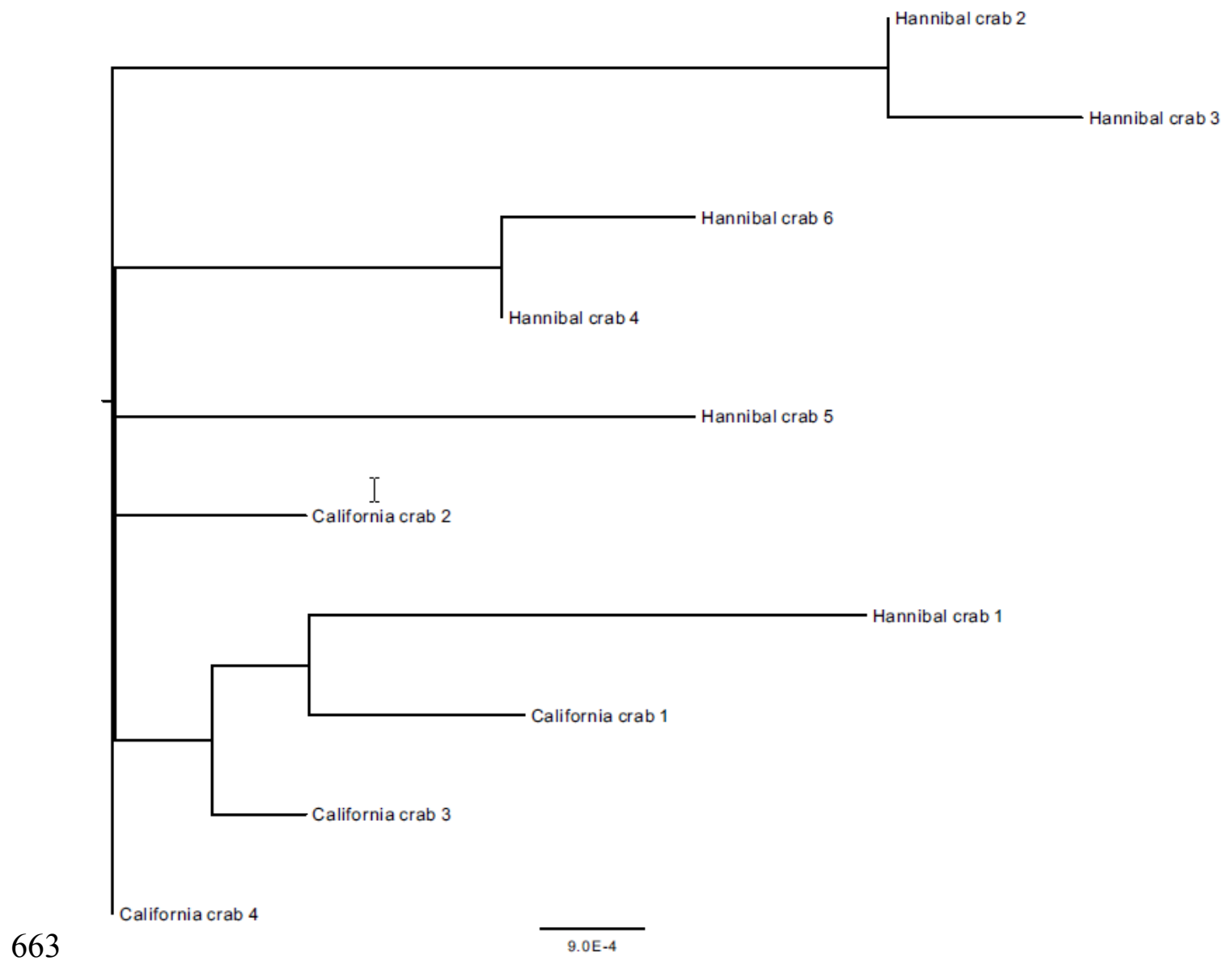

664 Fig. 6. Midpoint-rooted neighbor-joining topology based on mt COI Kimura 2-parameter

665 distances. Crab number 5 was found on 3 April at another location on Hannibal seamount, and 666 was not in an aggregation.

667 


\section{Pleuroncodes planipes density with depth}

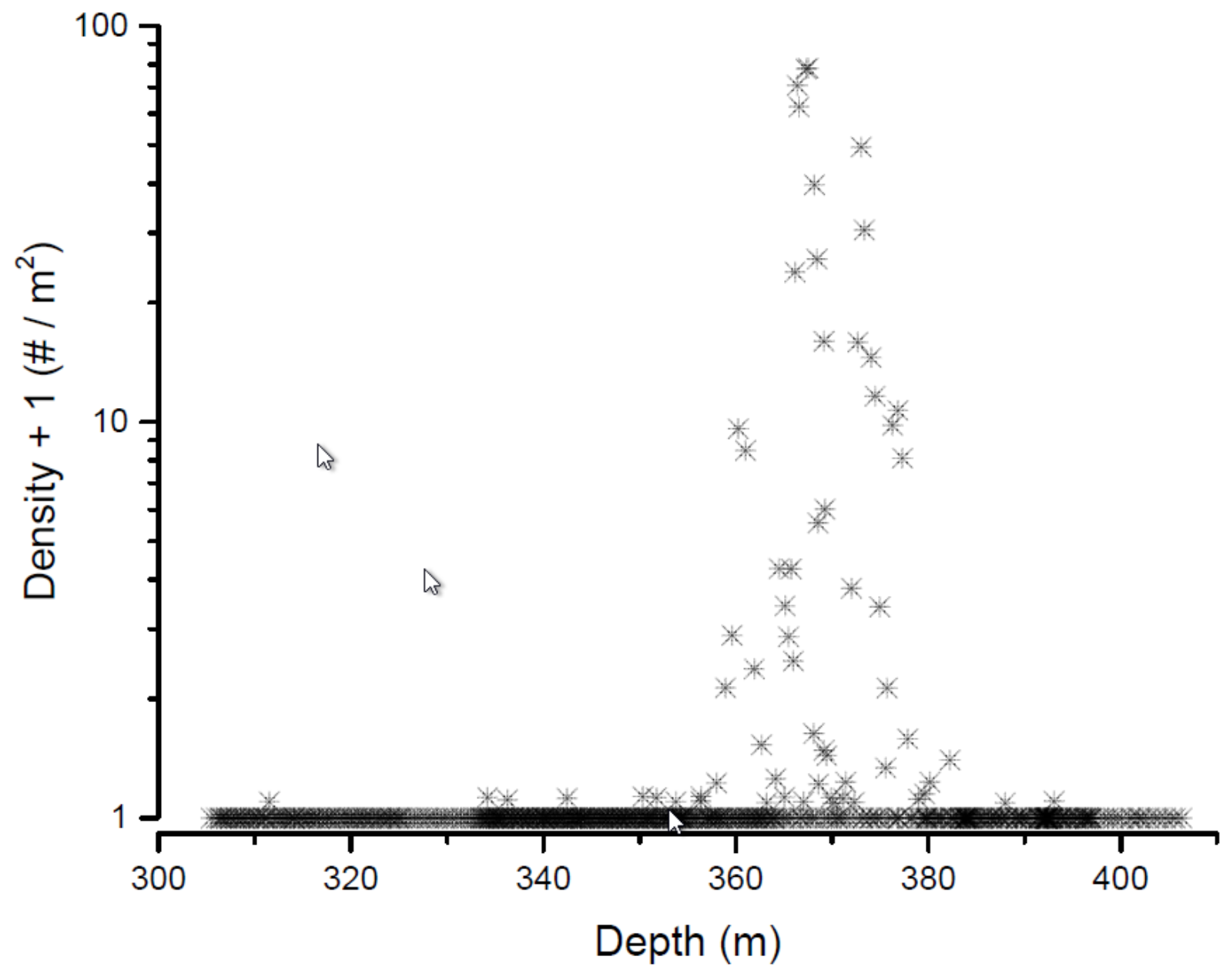

669 Fig. 7. Pleuroncodes planipes density with depth.

670 


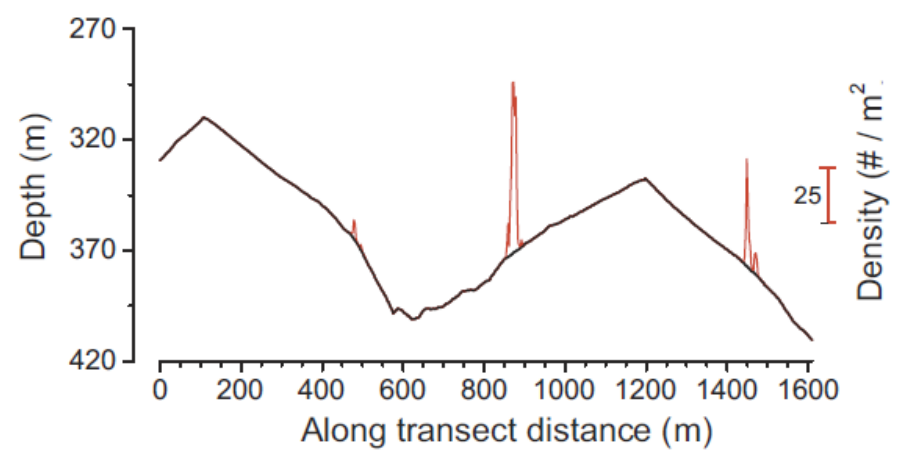

671

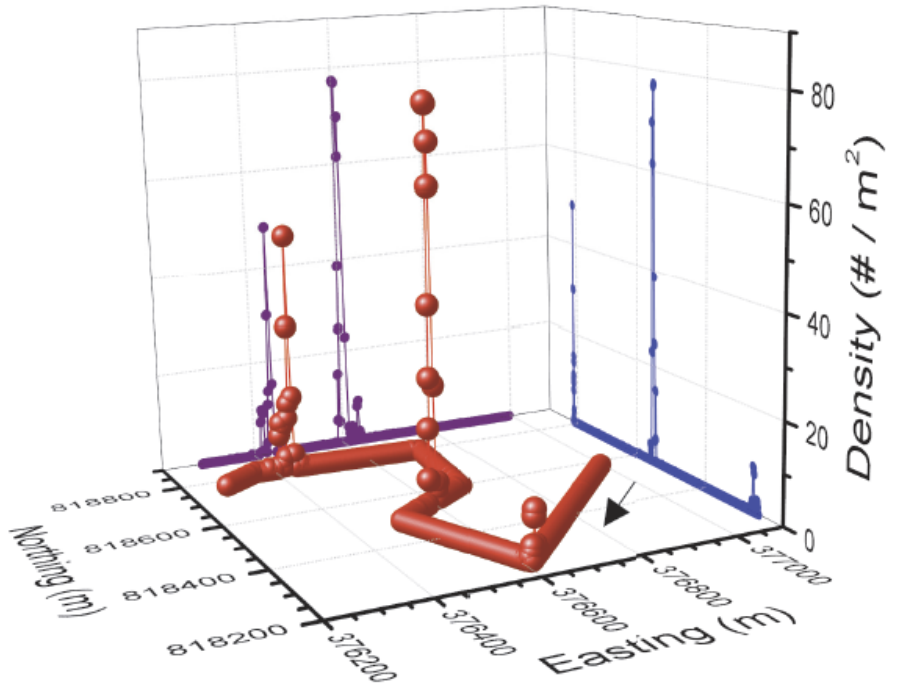

672 Fig. 8. Along transect Pleuroncodes planipes density on depth (top panel), and 3-d plot of

673 density with latitude and longitude. Arrow on bottom panel indicates the direction of the transect.

674 

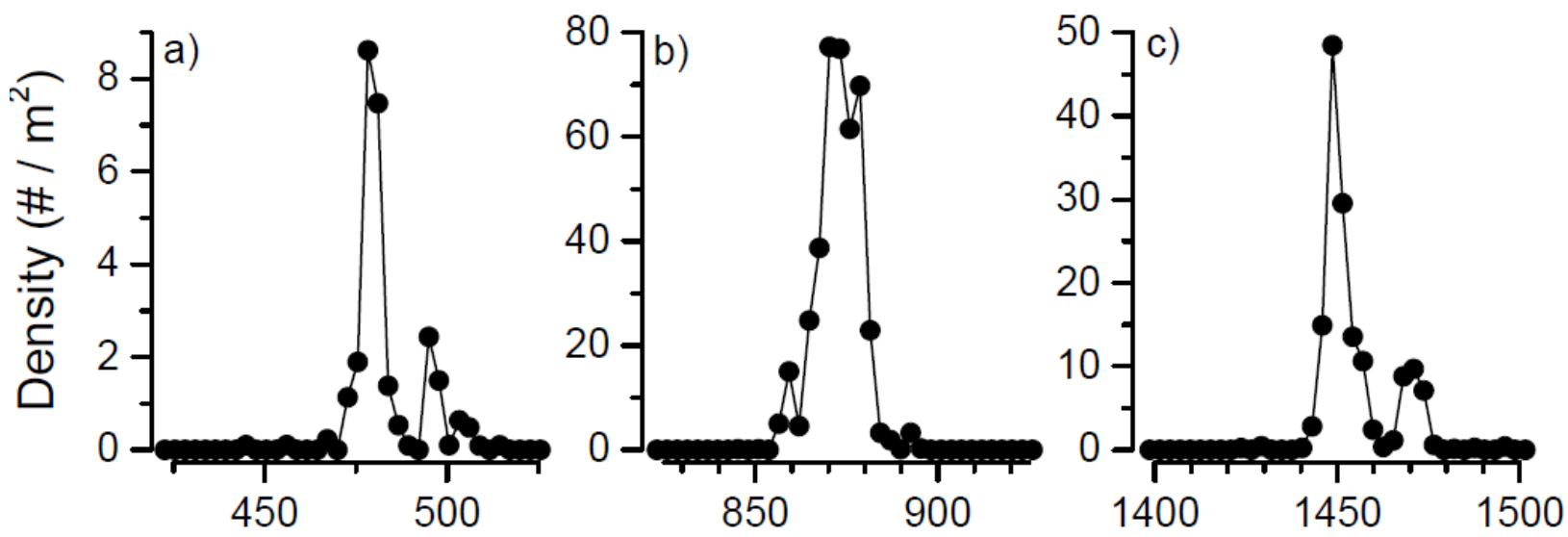

675

Along transect distance $(\mathrm{m})$

676 Fig. 9. Pleuroncodes planipes abundance distribution in each one of the three density peaks in

677 Fig. 8. For peak correspondence, see along transect distance and maximum density.

678 
18 April 2015
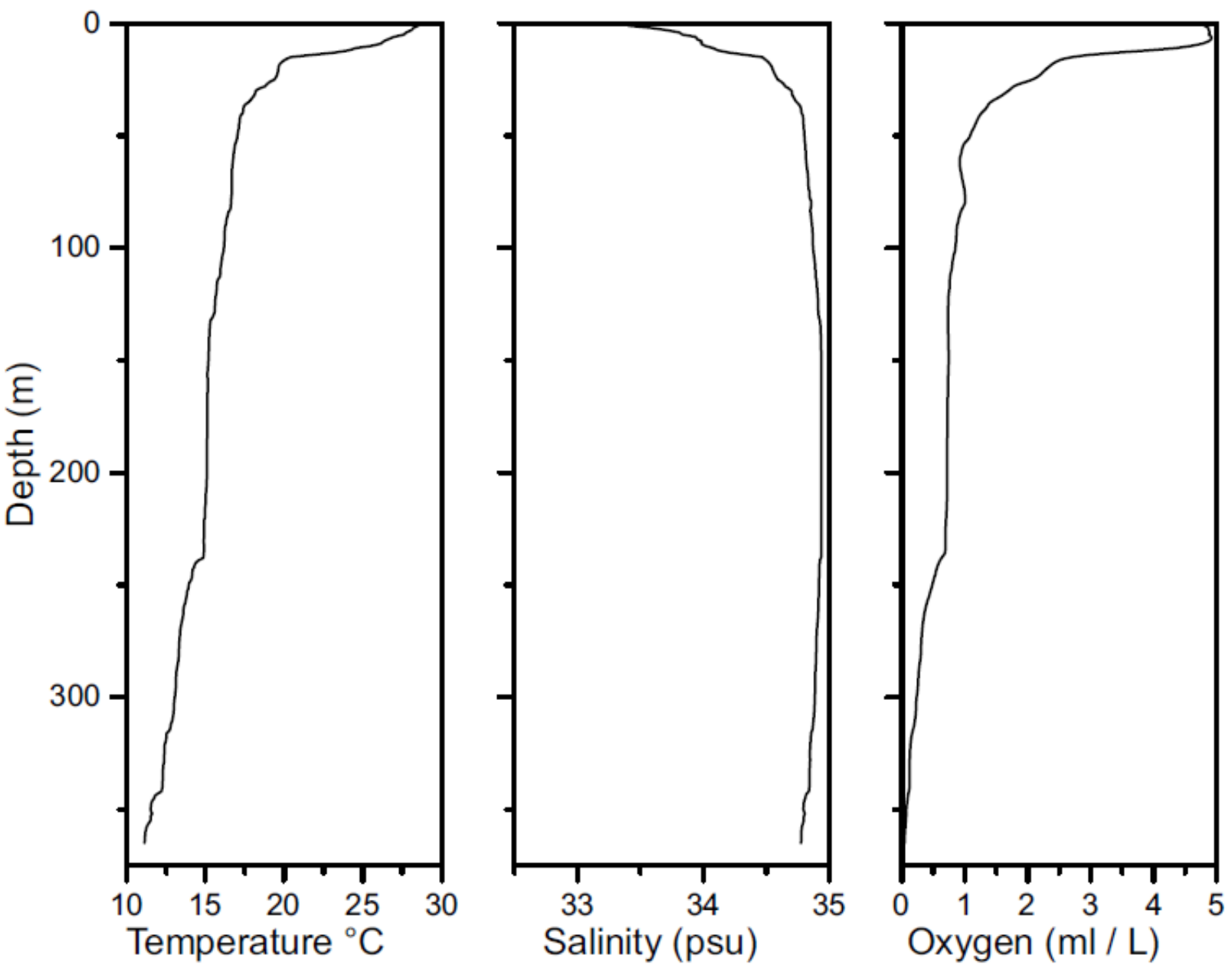

680 Fig. 10. Temperature, salinity and oxygen profile measurements taken with a CTD on 18 April 6812015 at a station a few tens of meters from the Seabed AUV transects. 